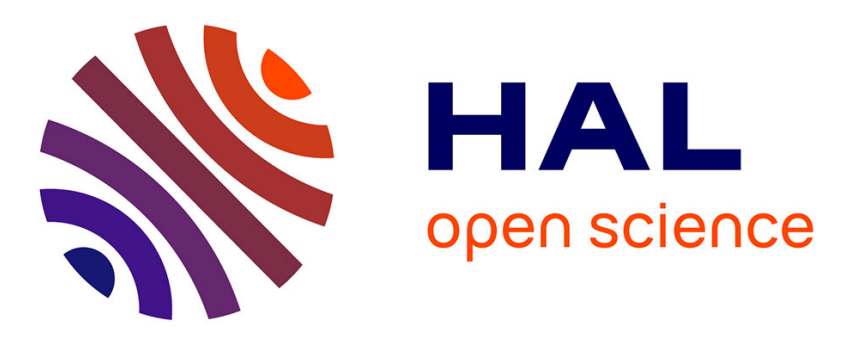

\title{
Diatom quantification and their distribution with salinity brines in coastal sediments of terra nova bay (antarctica)
}

Franco Baldi, Chiara Facca, Davide Marchetto, Thi Nhu Mai Nguyen, Roberto Spurio

\section{To cite this version:}

Franco Baldi, Chiara Facca, Davide Marchetto, Thi Nhu Mai Nguyen, Roberto Spurio. Diatom quantification and their distribution with salinity brines in coastal sediments of terra nova bay (antarctica). Marine Environmental Research, 2011, 71 (4), pp.304. 10.1016/j.marenvres.2011.02.005 . hal00682418

\section{HAL Id: hal-00682418 \\ https://hal.science/hal-00682418}

Submitted on 26 Mar 2012

HAL is a multi-disciplinary open access archive for the deposit and dissemination of scientific research documents, whether they are published or not. The documents may come from teaching and research institutions in France or abroad, or from public or private research centers.
L'archive ouverte pluridisciplinaire HAL, est destinée au dépôt et à la diffusion de documents scientifiques de niveau recherche, publiés ou non, émanant des établissements d'enseignement et de recherche français ou étrangers, des laboratoires publics ou privés. 


\section{Accepted Manuscript}

Title: Diatom quantification and their distribution with salinity brines in coastal sediments of terra nova bay (antarctica)

Authors: Franco Baldi, Chiara Facca, Davide Marchetto, Thi Nhu Mai Nguyen, Roberto Spurio

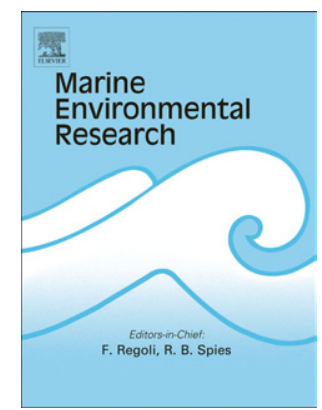

PII:

S0141-1136(11)00032-8

DOI:

10.1016/j.marenvres.2011.02.005

Reference: MERE 3511

To appear in: Marine Environmental Research

Received Date: 30 November 2010

Revised Date: 15 February 2011

Accepted Date: 18 February 2011

Please cite this article as: Baldi, F., Facca, C., Marchetto, D., Nguyen, M., Spurio, R. Diatom quantification and their distribution with salinity brines in coastal sediments of terra nova bay (antarctica), Marine Environmental Research (2011), doi: 10.1016/j.marenvres.2011.02.005

This is a PDF file of an unedited manuscript that has been accepted for publication. As a service to our customers we are providing this early version of the manuscript. The manuscript will undergo copyediting, typesetting, and review of the resulting proof before it is published in its final form. Please note that during the production process errors may be discovered which could affect the content, and all legal disclaimers that apply to the journal pertain. 


\title{
DIATOM QUANTIFICATION AND THEIR DISTRIBUTION WITH SALINITY BRINES IN COASTAL SEDIMENTS OF TERRA NOVA BAY (ANTARCTICA)
}

\author{
Franco Baldi, ${ }^{1}$ Chiara Facca ${ }^{1}$, Davide Marchetto ${ }^{1}$, \\ Thi Nhu Mai Nguyen ${ }^{2}$, Roberto Spurio ${ }^{2}$
}

1-Department of Environmental Sciences, Ca' Foscari University, Calle Larga S. Marta Dorsoduro 2137, 30123 Venezia, Italy

2-Laboratory of Molecular Biology and Microbial Biotechnologies, Department of Biosciences and Biotechnologies, University of Camerino, Via Gentile III da Varano; 62032 Camerino (MC) Italy

Correspondence: Franco Baldi, Department of Environmental Science Cà Foscari University of Venezia, Tel. 041.2348901, baldi@unive.it 


\section{Abstract}

Benthic diatoms represent an important element of global nutritional productivity; to raise attention on their role, which is often neglected due to analytical difficulties, surface (1 $\mathrm{cm}$ top layer) coastal sediments from Gerlache inlet to Penguin Bay at Terra Nova Bay were collected and stored at $-20^{\circ} \mathrm{C}$. DNA amplification by real-time-PCR, based on diatomspecific oligonucleotide primers designed on small-subunit rRNA (SSU rRNA), was performed in addition to diatom conventional cell counting and spectrophotometric determination of photo-pigments. Moreover, cations and anions were determined in sediments with the aim to identify factors involved in the control of diatom abundance.

Diatom distribution was found quite heterogeneous displaying significant differences from site to site. The salinity in sediments ranged from 45.1 at Gerlache inlet to 76.2 at Penguin Bay and it was correlated with cell abundance, biodiversity, amount of pigments and amplified DNA. The dominant species, Fragilariopsis curta, was associated to sediment salinity brines.

Keywords: diatoms, real-time PCR, coastal sediments, SEM-EDX analyses, salinity brines, Terra Nova Bay.

\section{Introduction}

Diatoms are responsible for a substantial part of the carbon fixation (Arrigo et al., 1999), especially at Ross Sea (Antarctica), which is characterized by relatively high primary productivity due to the Polynya phenomenon. Pennate diatoms can be found in water column and in sediments and, at high latitudes they are the most conspicuous organisms in the pack ice, where they could reach such high concentrations that their photosynthetic pigments discolor the ice brown (Thomas and Dieckman, 2002). Several diatom species have been found in this harsh habitat, where low ice temperatures are 
linked to high levels of salinity brine (Zhang et al., 1999). These unicellular photosynthetic microalgae are mainly found on the underside of the ice where the light is more intense than in the rest of the water column. However, their abundance can be significant also in the surface sediments of the coastal zone where the light reaches the bottom and in some areas they were found to be more productive than phytoplankton (Brotas and Catarino, 1995; Cabeçadas et al., 2000). Several pennate diatoms manage to migrate through sediment layers but $80 \%$ of the living community is concentrated in the top few millimiters (Maclntyre et al., 1996).

Diatom colonization of sediments is a poorly studied topic due to sampling and analytical difficulties. Microscopy observations are complicated by the presence of sediment grains and organic matter, hence, frustule cleaning with acids or hydrogen peroxide is essential. In such conditions the distinction between live cells, dead cells still carrying intact biomolecules and empty frustules is very difficult to achieve. However, as it is still unclear which may be the role of benthic diatoms in the sediment organic carbon enrichment, it is of primary interest to improve the investigation methods and to obtain coherent correlation among data. Moreover, recent in situ productivity studies based on detection of biopolimeric carbon (BPC; the sum of carbon equivalents of proteins, carbohydrates and lipids) in coastal sediments at Terra Nova Bay during the Austral summer 2004-05 suggest a key role for diatoms (Baldi et al., 2010).

The few information available indicate that the dominant species in the settled material (hence coming from the water column) of the southwestern Ross Sea, as well as in the surface sediments North of Drygalski lce Tongue (Western Ross Sea, South of Terra Nova Bay), is Fragilaropsis curta, which is commonly associated with both sea ice and the retreating ice edge, suggesting that it is probably seeded by melting ice (Leventer and Dunbar, 1996, Cunningham and Leventer, 1998). F. curta was found to characterize the surface sediments also in other regions of the Antarctic shelf, such as Prydz Bay, 
representing up to the $60 \%$ of total diatoms (Rathburn et al., 1997).

The aim of this study was to provide information on diatom abundance and distribution in poorly studied coastal sediments of Terra Nova Bay (Ross Sea, Antarctica). Such organisms may represent an essential food source and it is important to understand their role in the trophic chain mainly in a region characterized by extreme environmental conditions but also able to guarantee the survival of high trophic level animals (e.g. penguins; Sweeney et al., 2000). In order to reduce the analytical difficulties linked to the determination of benthic community different techniques were used. Conventional cell counting was related to quantitative determination of photopigments, nutrients and PCR amplified DNA in the attempt to distinguish between DNA containing diatoms and empty frustules settled in the sediments. Moreover, the correlation between biological and chemical data may furnish indication on the factor controlling diatom distribution in such an extreme habitat.

\section{Materials and methods}

\subsection{Sampling area}

The study area and sampling protocol are described in Baldi et al. (2010). Coastal sediment samples (1 cm surface layer) were collected at Terra Nova Bay (Ross Sea, Antarctica) during the Italian Antarctic Expedition of January 2005. During the ice melt-out, samples were taken in seven different areas (Fig. 1). Stations A and B are located in Tethys Bay, station C is in Penguin Bay near a rookery, station D at Malippo Pier in the vicinity of the Italian Base; stations E, F and G are at Gerlache Inlet. The first centimeter of sediments was cored at water depths ranging between $19 \mathrm{~m}$ and $66 \mathrm{~m}$ along the coast (Baldi et al., 2010). Sediment samples were stored at $-20^{\circ} \mathrm{C}$ and freeze-dried depending on the analytical protocol. Sediment grain size varied from coarse-sand to sand (Dunbar et 
al., 1985). Sediment water content was estimated as the difference between wet and dry weights by drying at $60^{\circ} \mathrm{C}$ to constant weight.

\subsection{Diatom counting by light microscopy}

The frozen sediments were weighed and treated with $10 \mathrm{ml}$ of $10 \%(\mathrm{v} / \mathrm{v})$ hydrogen peroxide for 32 hours (Cunningham et al., 2005). The slurry was then diluted with $8 \mathrm{ml}$ of distilled water and centrifuged for $5 \mathrm{~min}$ at $3000 \mathrm{rpm}$. The supernatant was decanted and the sediment was suspended again in $10 \mathrm{ml}$ of distilled water. This process was repeated twice and then the sediment was resuspended in $10 \mathrm{ml}$ of water. The solution was gently homogenized and $200 \mu \mathrm{l}$ were allowed to settle on a $2 \mathrm{ml}$ microscope chamber for analysis on an inverted light microscope. At least 230 cells were counted and identified in random fields. The diatoms were taxonomically identified according to Peragallo and Peragallo (1897-1908), Tomas (1996), Vanlandingham (1967-79) and Round et al. (1990) and cell sizes were measured to estimate the carbon content (biomass) according to Edler's formulation (1979).

\subsection{Scanning Electron Microscopy and X-ray dispersive microanalyses}

An aliquot $(100 \mu \mathrm{g})$ of homogenized freeze-dried sediment for each sample was prepared to determine diatom frustules, sediment structure and elemental composition of particles by scanning electron microscopy energy dispersive X-ray microanalysis (SEM/EDX). Specimens were glued to standard vacuum-clean stubs and coated with graphite (Edwards, carbon scancoat, S150A) (Milanesi et al., 2009). Three specimens of each sediment sample were observed by SEM (Philips XL20) with an instrument equipped with an EDX DX4 probe, which was used at $20 \mathrm{kV}$ acceleration voltages to identify elements on the sediment surface by scanning different areas of each specimen. Mean 
concentrations and standard deviations of each detected element were calculated from ten random determinations at different spots on each specimen.

\subsection{Photopigment analysis}

Sediment samples for characterization of biochemical composition were freeze-dried and homogenized, paying attention to remove gravel and shell debris. Chlorophyll-a (Chl-a) and phaeophytine- $\mathrm{a}$ (Phaeo-a) were extracted from $2 \mathrm{~g}$ of sediment with $5 \mathrm{ml}$ acetone for $12 \mathrm{~h}$ at $4^{\circ} \mathrm{C}$; supernatants containing the extracted pigments were recovered by decanting

111 the supernatant after centrifugation (Lorenzen, 1967; Pusceddu et al., 2003). Chl-a and

112 Phaeo-a concentrations were determined spectrophotometrically at 750 and $665 \mathrm{~nm}$ 113 before and after acidification with $0.1 \mathrm{~N} \mathrm{HCl}$. These data provided an indication of the 114 pigment concentrations in the sediments without information on the taxonomic group that 115 produce them. However, it was observed that diatoms are often the dominant taxon 116 (Maclntyre et al., 1996; reference in Facca and Sfriso, 2007).

\subsection{Quantification of water-washed cations and anions}

119 Cations $\left(\mathrm{Na}^{+}, \mathrm{K}^{+}, \mathrm{Mg}^{2+}, \mathrm{Ca}^{2+}, \mathrm{NH}_{4}{ }^{+}\right)$and anions $\left(\mathrm{Cl}^{-}, \mathrm{SO}_{4}{ }^{2-}, \mathrm{PO}_{4}{ }^{3-}, \mathrm{NO}_{3}{ }^{-}\right)$were quantified to correlate the presence of diatoms with nutrients in salts precipitated on sediment particles.

121 Nutrients were washed out from $1 \mathrm{~g}$ of frozen sample with $50 \mathrm{ml}$ of milliRo water after 3

$122 \min$ vortexing at $5^{\circ} \mathrm{C}$. The supernatant was filtered through Whatman black ribbon 589/1.

123 An aliquot of $20 \mu \mathrm{l}$ was injected into a pre-loop filter with $0.45 \mu \mathrm{m}$ cartridge ionic

124 chromatograph (METROHM 761 Compact IC) with a conductimeter as detector. For anion 125 determination the chromatograph was equipped with a column METROSEP ASUPP5 150 $126 \mathrm{~mm} \times 4 \mathrm{~mm}$ with a mobile phase consisting of $\mathrm{NaHCO}_{3} 1 \mathrm{mM} / \mathrm{Na}_{2} \mathrm{CO}_{3} 3.2 \mathrm{mM}$ running at a 127 flow rate of $0.7 \mathrm{ml} \cdot \mathrm{min}^{-1}$; for cation determination the chromatograph was equipped with a 
METROSEP C3 $250 \times 4$ mm column with a mobile phase consisting of $\mathrm{HNO}_{3} 3 \mathrm{mM}$ working at $1 \mathrm{ml} \cdot \mathrm{min}^{-1}$. Salinity was calculated as $\mathrm{S}=1.80655 \mathrm{Cl}^{-}$.

\subsection{Real-time PCR}

132 Benthic diatom cells were prepared for the polymerase chain reaction (PCR) analysis by 133 diluting one gram of each sediment sample in $30 \mathrm{ml}$ of buffer $\mathrm{S}\left(880 \mu \mathrm{M} \mathrm{NaNO} \mathrm{N}_{3}, 36 \mu \mathrm{M}\right.$ $134 \mathrm{NaH}_{2} \mathrm{PO}_{4} \cdot \mathrm{H}_{2} \mathrm{O}$, and $\left.105 \mu \mathrm{M} \mathrm{Na} \mathrm{SiO}_{3} \cdot 9 \mathrm{H}_{2} \mathrm{O} \mathrm{pH} 7.5\right) .600 \mu \mathrm{l}$ of diluted sediment sample were filtered through nitrocellulose membrane (Millipore $0.45 \mu \mathrm{m}, 25 \mathrm{~mm} \varnothing$ ) to collect and concentrate diatoms that were extensively washed with $50 \mathrm{ml}$ of distilled water and then recovered using one $\mathrm{ml}$ of resuspension solution $(5 \mathrm{mM}$ Tris- $\mathrm{HCl}, 0.8 \%$ (v/v) Tween-20; $\mathrm{pH}$ 7.4) as described (Nguyen et al., 2010). $10 \mu$ laliquots of the cell suspension were dried in a speed-Vac, and frozen at $-80^{\circ} \mathrm{C}$. Immediately before use they were resuspended in $10 \mu \mathrm{l}$ of water, and $2 \mu \mathrm{l}$ were used for PCR. To inactivate nucleases which are commonly found in sediment samples, the concentrated cells were incubated at $95^{\circ} \mathrm{C}$ for $2^{\prime}$, before they were used as source of template for PCR. As shown in Fig 1S (Supplementary materials) the presence of different amounts of nucleases in the seven sediment samples did not interfere with the molecular analysis. DNA amplification by PCR was carried out essentially as described (Nguyen et al., 2010) using genomic DNA released from diatom cells upon the initial denaturation step in the thermal cycler. Primers used in this study (528F 5' GCGGTAATTCCAGCTCCAA and 650R 5' AACACTCTAATTTTTTCACAG) target the small subunit ribosomal DNA gene (SSU rRNA) and produce an amplicon of approximately 200 bp suitable for real-time PCR. These primers have already been tested using environmental samples and proved to correlate with diatom abundance measured by light microscopy counting (Nguyen et al., 2010). This primer set, though originally

152 developed for detection of freshwater diatoms, exhibits $100 \%$ similarity with most of the sequences of marine diatoms available. The relative amount of SSU rRNA of various 
154

155

156

diatoms found in coastal sediments was determined by the standard curve-based method.

Standard DNA corresponding to a portion of SSU rRNA was prepared as an amplified 1040 bp long DNA fragment purified by a DNA clean-up kit; its concentration was spectrophotometrically determined. For the calibration curve this DNA was used as a series of four 10 -fold dilutions. Three replicates of each sediment sample and four replicates of each point of the standard curve were analysed. The efficiency of real-time PCR amplification was $95.6 \%$. Real-time PCRs were carried out, according to the manufacturer's protocol (Qiagen Quantitech SYBR Green Kit), in a $20 \mu$ l volume containing $0.3 \mu \mathrm{M}$ each primer and $2 \mu \mathrm{l}$ of biomass corresponding to $40 \mu \mathrm{g}$ of sediment sample. The DNA amplification regime was 15 min at $95^{\circ} \mathrm{C}$ followed by 40 cycles of $94^{\circ} \mathrm{C}$ for $15 \mathrm{~s}, 50^{\circ} \mathrm{C}$ for $1 \mathrm{~min}$, and $72^{\circ} \mathrm{C}$ for $30 \mathrm{~s}$. Cycle threshold (Ct) data were collected from an MxPro-Mx3000P instrument (Stratagene).

\section{Results and discussion}

Diatoms, which attain such high concentrations as to discolor the ice brown, generally dominate the ice-edge blooms; their high primary productivity $\left(1.3 \mathrm{~g} \mathrm{C} \cdot \mathrm{m}^{-2} \cdot \mathrm{d}^{-1}\right)$ could explain the high amount of biogenic siliceous sediments and the large population of high trophic level animals (Sweeney et al., 2000 and references therein). For example, in Terra Nova bay in 1998, the phytoplankton bloom, which reached approximately $8 \times 10^{8}$

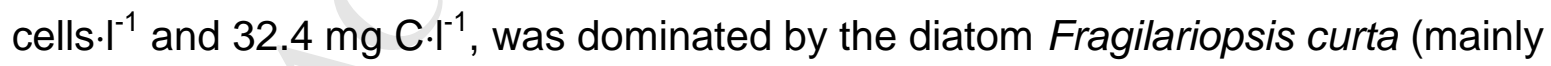
planktonic species), whereas in other areas of the Ross Sea abundances $>86 \times 10^{3}$ cells.$^{-}$ ${ }^{1}$ and $11.7 \mu \mathrm{g} \mathrm{C} \cdot \mathrm{I}^{-1}$ were mainly due to the Prymnesiophyceae Phaeocystis antarctica (Fonda Umani et al., 2005).

In this study, 23 diatom species were identified in the seven studied sites (Table 1).
The genera Fragilariopsis (Fig. 2 A, B, E), Navicula and Thalassiosira (Fig. 2, C) were 
recorded in all stations. The occurrence and abundance of other genera varied in relation to the site: Amphora (Fig. 2 D, E) was abundant ( 4\%) at rookery station (C) but absent at stations A, E, G; Luticola reached up to $5 \%$ at the less deep station (D) but was not recorded in the other sites; Nitzschia exceeded 10\% at station A (Tethys Bay) but was not observed at stations B, in the same basin and with similar depth and salinity.

All the observations highlighted that the communities were markedly dominated by F. curta (>70\%; Table 2) (Fig. 2-A), whose pelagic and benthic distribution in the Antarctic area was already reported (Rathburn et al., 1997; Fonda Umani et al., 2005). Benthic diatom biodiversity index tended to decrease with increasing water column depth, from $3,02 \mathrm{H}^{\prime}$ at $19 \mathrm{~m}$ to $1,04 \mathrm{H}^{\prime}$ at $48 \mathrm{~m}$, where the solar radiation is lower and few diatom species are sciaphilous (adapted to low light intensity).

The lowest cell abundance was found at the stations with salinity below 50 ( $D$ and $F$ ), and the highest number of species was detected at station $D$ (Table 2) with a major contribution of Fragilariopsis rhombica and Navicula spp. whose relative abundance altogether was close to $45 \%$. In addition, the sediments of stations $\mathrm{D}$ and $\mathrm{F}$ contain a higher percentage of sand than those of other five stations, and it is known that grain size and sediment density can significantly influence abundance and diversity of benthic diatoms (Facca and Sfriso, 2007 and references therein). The genera Amphora, Cocconeis, Luticola, Navicula and Nitzschia, which are typical of benthic habitats (Round et al., 1990), contributed significantly to the abundance and diversity of stations characterized by low salinity ( $D$ and $F$ ), whereas they were rare at the deepest stations ( $G$ and $E$;Table 1). Chl-a, ranging from $0.44 \mu \mathrm{g} \cdot \mathrm{g}^{-1}$ at the station $(\mathrm{F})$ with the lowest salinity to $11.0 \mu \mathrm{g} \cdot \mathrm{g}^{-1}$ at the station $(\mathrm{C})$ with the highest salt content (Table 2), provides general information concerning all primary producers. The $\mathrm{Chl}-\mathrm{a} / \mathrm{Pheo}-\mathrm{a}$ ratio gives also an indication of the metabolic state of the diatom community, and the values, ranging from 
0.22 at station $D(19 \mathrm{~m})$ to 0.08 at station $E(69 \mathrm{~m})$, suggest a condition of progressive degradation of the photoautotrophic community.

Real-time PCR based on diatom-specific oligonucleotide primers designed on the SSU rRNA was used to identify the DNA-containing diatoms (Nguyen et al., 2011). Thus, the chromosomal DNA of diatoms was used as molecular target with the aim to count and distinguish DNA-containing cells from empty frustules. at Gerlache inlet (station F). The amount of SSU rRNA detected by real-time PCR was consistently higher in sample $\mathrm{C}$, characterized by the highest salinity, compared to all other stations examined (Fig. 3). We can conclude that sediments at station $\mathrm{C}$ present the highest concentration of photo-pigments and amplified SSU rRNA, and these features correlate well with the abundance of frustules. Of the 23 diatom species described in this study, the SSU rRNA gene sequence of only three species is available in public databases. A thorough DNA sequencing study of the remaining diatom species would be interesting, as it would corroborate the microscopy data with molecular data, and would provide a more refined phylogenetic view.

Why are sediments at Penguin Bay (station C) so rich in diatoms? To answer this question, we focused our attention on the chemical composition of superficial sediment grains in all stations; each sediment specimen was examined by SEM/EDX and a semiquantitative analysis of major elements was carried out by means of $X$ ray emission. The sediment particles were patched with copious diatom assemblages with some siliceous spicules belonging to Porifera (Fig. 4). The sediment particles were constituted mainly by silica $(15.5 \% \pm 2.77, n=10)$, oxygen $(54.1 \% \pm 2.97, n=10)$, aluminum $(3.44 \pm 1.9, n=10)$ and other less represented elements (<1\%), while microbial assemblages (Fig. 4) were enriched in $\mathrm{K}(3.67 \% \pm 1.21), \mathrm{Na}(2.75 \% \pm 1.01)$, and $\mathrm{Cl}(1.57 \% \pm 0.87)$. These data suggest the presence of salinity brines (Frank et al., 2010) associated with diatom deposits 
on sediment particles. In water leached sediments the presence of salinity brines was confirmed by cation and anion determination (Table 3). The sum of the concentrations (mg.g ${ }^{-1}$ d.w.) of $\mathrm{Na}^{+}, \mathrm{K}^{+}, \mathrm{Mg}^{2+}$, and $\mathrm{SO}_{4}{ }^{2-}$ are consistent with the amounts of $\mathrm{Cl}^{-}$and the calculated salinity ranged between 45.1 and 75.2. $\mathrm{NO}_{3}{ }^{-}$was almost constant in all stations, whereas some soluble nutrients such as $\mathrm{PO}_{4}{ }^{3-}$ and $\mathrm{NH}_{4}{ }^{+}$with acetate traces were more concentrated in stations $A$ and $B$ confirming the high fermenting activity in semi-enclosed Tethys Bay (Baldi et al., 2010). Finally, the low content of water in all samples (range $29 \%$ $18 \%$ ) confirmed the prevalent sandy composition of sediments.

The highest salinity (76.2) was found at station C, concomitant with the highest diatom concentration. This high value of salinity is not surprising since associations of diatoms with salinity brines displaying values higher than 200 were previously reported (Cox and Weeks, 1983).

All the analyses clearly indicated a marked difference between the community at station $\mathrm{C}$ and the other stations. In fact, at station $\mathrm{C}$ most of Fragilariopsis spp. cells were presumably either live cells or, if dead diatoms, they were still containing active biomolecules, as confirmed by high chlorophyll concentrations and high amount of amplified SSU rRNA gene. Although the number of samples available was relatively low, high correlation factors $\left(r^{2}>0.9\right)$ were found between salinity and biodiversity index (Fig. 5A) and photopigment ratios (Fig. 5B), with the exception of stations $D$ and F. These sediments were characterized by the lowest salinity $(<50)$, water content $(18 \%)$ and $\mathrm{Na}^{+}$, $\mathrm{Mg}^{2+}, \mathrm{SO}_{4}{ }^{2-}, \mathrm{PO}_{4}{ }^{3-}$ concentrations. On the other hand biodiversity indices were the highest and few F. curta frustules were recorded. Salinity was also correlated with the amount of SSU rRNA (Fig. 5C) and the number of frustules belonging to F.curta (Fig. 5D) except for sediments at stations $A, B$ and $E$, where diatoms contained low amounts of detectable DNA compared with total frustule abundance, and showed fewer $F$. curta frustules than in stations $F, D, G$ and $C$. At stations A and B (Tethys Bay) sediments were prevalently 
anoxic (Baldi et al., 2010) and probably diatoms had settled from ice pack and water column and were predated by heterotrophic bacteria. At station $\mathrm{E}$, sediments were those collected at the deepest level $(66 \mathrm{~m})$ and the lowest photo-pigments ratio detected reflects the scarce solar irradiation. Therefore, we hypothesize that most of the diatoms found at station $E$ were probably not viable cells and the frustules probably were transported from shallow to deeper waters by pycnoclinic currents (Frignani et al., 2003). In station $\mathrm{C}$, we found a strong correlation between the abundance of DNAcontaining diatoms (among which Fragilariopsis cells were the most represented) and the level of salinity which is the highest in seawaters of that region (Fonda Umani et al., 2005). (Fig. 5C). This result is consistent with other reports where Fragilariopsis was found to be able to cope with high salt concentration and low temperatures, which are the necessary conditions for the expression of ice antifreeze proteins (AFPs) (Bayer-Giraldi et al., 2010). AFP production is involved in cold adaptation contributing to the successful reproduction of Fragilariopsis and perhaps of other polar diatom species.

\section{Conclusion}

In this study, the integration of data derived from standard ecological parameters with results obtained from quantitative detection of diatom DNA using molecular tools, allowed us to monitor the physiological status of diatoms within a complex community. The determination of biological, biochemical and chemical parameters in coastal sediments of Terra Nova Bay focus the attention on salinity as the major parameter influencing diatom distribution and growth. Variations in salt concentration, rather than the amounts of nutrients available, appeared to be the most important environmental factor influencing the 279 growth of $F$. curta. Biodiversity index instead, shows that high salinity levels represent a 280 discrimination factor that might limit the development of a panel of different diatom 281 species. This is true for sediments at Penguin Bay, where F.curta, an organism adapted to 
living in hypersaline conditions, markedly dominates over all the other species. This finding

confirms that only few diatom species, compared with the million of existing diatom species, are adapted to thrive at high salinity.

\section{Acknowledgements}

This work was supported by grants from PNRA (Programma Nazionale delle Ricerche in Antartide) PEA 2003-2005 Research Project. The authors thank Angelina Lo Giudice and

Luigi Michaud for providing sediment samples and Cynthia L. Pon for critical reading of the manuscript.

\section{References}

Arrigo, K.R., Robinson, D.H., Worthen, D.L., Dunbar, R.B., DiTullio, G.R., VanWoert, M., Lizotte, M.P., 1999. Phytoplankton community structure and the drawdown of nutrients and $\mathrm{CO}_{2}$ in the Southern Ocean. Science 283, 365-367.

Baldi, F., Marchetto, D., Pini, F., Fani, R., Michaud, L., Lo Giudice, A., Berto, D., Giani, M., 2010. Biochemical and microbial features of shallow marine sediments along the Terra Nova Bay (Ross Sea, Antarctica). Continental Shelf Research 30, 1614-1625.

Bayer-Giraldi, M., Uhlig, C., John, U., Mock, T., Valentin, K. 2010. Antifreeze proteins in polar sea ice diatoms: diversity and gene expression in the genus Fragilariopsis. Environmental Microbiology 12, 1041-1052.

Brotas, V., Catarino, F., 1995. Microphytobenthos primary production of Tagus estuary intertidal flats (Portugal). Netherlands Journal of Aquatic Ecology 29, 33-339.

Cabeçadas, G., Brogueira, M.J., Cabeçadas, L., 2000. Southern Portugal: the Tagus and Sado estuaries. In: Sheppard, C. (Ed.), Seas at The Millennium-An Environmental Evaluation. Regional Chapters: Europe, The Americas and West Africa. Pergamon, 
Oxford, pp. 151-165.Cox, G.F.N., Weeks, W.F., 1983. Equation for determining the gas and brine volumes in sea-ice samples. Journal of Glaciology 29, 306-316.

Cunningham, W.L., Leventer, A., 1998. Diatom assemblages in surface sediments of the Ross Sea: relationship to present oceanographic conditions. Antarctic Science

$$
\text { 10,134-146. }
$$

Cunningham, L., Snape, I., Stark, J.S., Riddle, M.J., 2005. Benthic diatom community response to environmental variables and metal concentrations in a contaminated bay adjacent to Casey Station, Antarctica. Marine Pollution Bulletin 50, 264-275.

Dunbar, R.B., Anderson, J.B., Domack, E.W., Jacobs, S.S., 1985. Oceanographic influences on sedimentation along the Antarctic continental shelf. Antarctic Research series 43, 291-312.

Edler, L., 1979. Recommendations for marine biological studies in the Baltic Sea. Phytoplankton and Chlorophyll. Baltic Marine Biologists Publication 5, 1-38.

Eicken, H., 1992. The role of sea ice in structuring Antarctic ecosystems. Polar Biology 12, 3-13.

Facca, C., Sfriso, A., 2007. Epipelic diatom spatial and temporal distribution and relationship with the main environmental parameters in coastal waters. Estuarine Coastal and Shelf Science 75, 35-49.

Fonda Umani, S., Monti, M., Bergamasco, A., Cabrini, M., De Vittor, C., Burba, N., Del Negro, P., 2005. Plankton community structure and dynamics versus physical structure from Terra Nova Bay to Ross Ice Shelf (Antarctica). Journal of Marine Systems 55, 31-46.

Frignani, M., Giglio, F., Accornero, A., Langone, L., Ravaioli, M., 2003. Sediment characteristics at selected sites of the Ross Sea continental shelf: does the sedimentary record reflect water column fluxes? Antarctic Science 15, 133-139.

Leventer, A., Dunbar, R.B., 1996. Factors influencing the distribution of diatoms and other 
algae in the Ross Sea. Journal of Geophysical Research - Oceans 101,1848918500.

Lorenzen, C.J., 1967. Determination of chlorophyll and pheo-pigments: spectrophotometric equations. Limnology and Oceanography 12, 343-346.

Medlin, L., Elwood, H.J., Stickel, S., Sogin, M.L., 1988. The characterization of enzymatically amplified eukaryotic 16S-like rRNA-coding region. Gene 71, 491-499.

Milanesi, C., Baldi, F., Borin, S., Brusetti, L., Ciampolini, F., lacopini, F., Cresti, M., 2009. Deterioration of medieval painting in the chapel of the Holy Nail, Siena (Italy) partially treated with Paraloid B72. International Biodeterioration \& Biodegradation 63, 844-850.

Nguyen, T.N.M., Berzano, M., Gualerzi, C.O., Spurio, R., 2010. Development of molecular tools for the detection of freshwater diatoms. Journal of Microbiological Methods. In press.

Peragallo, M.M.H., Peragallo, M., 1897-1908. Diatomées Marines de France et des Districts Maritimes Voisins. MJ Tempere, Grez-sur-Loing.

Pusceddu, A., Dell'Anno, A., Fabiano, M., Danovaro, R., 2003. Quantità e composizione biochimica della materia organica nei sedimenti marini. Biologia Marina Mediterranea 10, 43-60.

Rathburn, A.E., Pichon, J.J., Ayress, M.A., De Deckker, P., 1997. Microfossil and stableisotope evidence for changes in Late Holocene palaeoproductivity and palaeoceanographic conditions in the Prydz Bay region of Antarctica. Palaeogeography Palaeoclimatology Palaeoecology 131, 485-510.

Round, F.E., Crawford, R.M., Mann, D.G., 1990. The Diatoms. Biology and Morphology of 
the genera. Cambridge University Press, Cambridge.

361 Sweeney, C., Hansell, D.A., Carlson, C.A., Codispoti, L.A., Gordon, L.I., Marra, J., Millero, F.J., Smith, W.O., Takahashi, T., 2000. Biogeochemical regimes, net community production and carbon export in the Ross Sea, Antarctica. Deep-Sea Research Part II-Topical Studies in Oceanography 47, 3369-3394.

Thomas, D.N., Dieckmann, G.S., 2002. Ocean Science - Antarctic Sea ice - a habitat for extremophiles. Science 295, 641-644.

Tomas, C.R., 1996. Identifying Marine Diatoms and Dinoflagellates. Academic Press, San Diego.

Vanlandingham, S.L., 1967-79. Catalogue of the fossil and recent genera and species of diatoms and their synonyms. J. Cramer, Vaduz.

Vrieling, E.G., Sun, Q.Y., Tian, M., Kooyman, P.J., Gieskes, W.W.C., van Santen, R.A., Sommerdijk, N.A.J.M., 2007. Salinity-dependent diatom biosilicification implies an important role of external ionic strength. Proceedings of the National Academy of Sciences of the United States of America 104, 10441-10446.

Zhang, Q., Gradinger, R., Spindler, M., 1999. Experimental study on the effect of salinity on growth rates of Arctic-sea-ice algae from the Greenland Sea. Boreal 


\section{Figure Captions}

387 Fig. 1. Sampling sites of coastal sediments at Terra Nova Bay from Gerlache Inlet to 388 Penguin Bay adjacent to the Italian Base.

390 Fig. 2 Photographs of six diatom species identified in the superficial sediments.

391 A: Fragilariopsis curta small size one $30 \mu \mathrm{m} \times 8 \mu \mathrm{m}$; large size one $40 \mu \mathrm{m} \times 9 \mu \mathrm{m}$

392 B: Fragilariopsis rhombica size $23 \mu \mathrm{m} \times 12 \mu \mathrm{m}$

393 C: Thalassiosira lentiginosa diameter $60 \mu \mathrm{m}$

394 D: Amphora ovalis size $55 \mu \mathrm{m} \times 25 \mu \mathrm{m}$

395 E: Fragilariopsis spp., Amphora sp.

396 F: Cocconeis costata size $45 \mu \mathrm{m} \times 25 \mu \mathrm{m}$

397 Amphora and Cocconeis (together with Navicula, Nitzschia) are typical of benthic habitat.

Fig. 3. The real-time PCR histogram showing the relative amount of diatom DNA found in the seven stations. The calibration curve consisted of serial 10-fold dilutions of the 1040 401 bp fragment described in the materials and methods section. The standard curve showed 402 a linear response from $3.5 \mathrm{fg}$ to $35 \mathrm{pg}$ of DNA $\left(r^{2}=0.981\right)$. The error bars represent 403 standard deviations.

Fig.4 (A) SEM micrographs of sediments from station C showing diatom aggregates.

Diatom frustules and debris are closely associated with some Porifera spicula. (B) X-ray dispersive microanalyses of a spot (square) indicating peaks of $\mathrm{Cl}$ and $\mathrm{Na}$ (arrows).

Fig. 5 Significant correlation of salinity versus the amount of amplified SSU rRNA

410 (AmpDNA; graph A), chlorophyll a/phaeopigment a ratio (Chl-a/Phaeo a; graph B),

411 Shannon diversity index (graph C) and Fragilariopsis curta (graph D). 


\section{ACCEPTED MANUSCRIPT}

Table 1. Floristic list of taxa identified at the light microscope analysing frozen samples. The presence in each station is marked by $\mathrm{a} X$.

\begin{tabular}{|c|c|c|c|c|c|c|c|c|}
\hline \multirow[t]{2}{*}{ Taxa } & \multirow[t]{2}{*}{ Species Authors } & \multicolumn{7}{|c|}{ Station } \\
\hline & & $A$ & B & C & $\mathrm{D}$ & $E$ & $\mathrm{~F}$ & $G$ \\
\hline Achnanthes brevipes & C. Agardh & & & $x$ & $x$ & & & $x$ \\
\hline Amphora ovalis & (Kützing) Kützing & & & $x$ & $x$ & & $x$ & \\
\hline Amphora sp. & & & $x$ & $x$ & & & $x$ & \\
\hline Cocconeis costata & Gregory & & & $x$ & $x$ & & & \\
\hline Cocconeis cfr. molesta & Kützing & & & & $x$ & $x$ & ) & \\
\hline Cocconeis cfr. scutellum & Ehrenberg & & $x$ & & $x$ & & $x$ & \\
\hline Fragilariopsis curta & (Van Heurck) Hustedt & $x$ & $x$ & $x$ & $x$ & $x$ & $x$ & $x$ \\
\hline Fragilariopsis kerguelensis & (O'Meara) Hustedt & $x$ & $x$ & $\mathrm{X}$ & $x$ & $x$ & & $x$ \\
\hline Fragilariopsis rhombica & (O'Meara) Hustedt & $x$ & $x$ & $x$ & $x$ & $x$ & $x$ & $x$ \\
\hline Fragilariopsis sp. & & & & & & & & \\
\hline Luticola sp. A & & & & & $x$ & & $x$ & \\
\hline Luticola sp. B & & & & & $x$ & & & \\
\hline Navicula directa & (W. Smith) Ralfs & $x$ & $x$ & $x$ & $x$ & $x$ & $x$ & $x$ \\
\hline Navicula sp. A (25 $\mu \mathrm{m})$ & & & & $\mathrm{x}$ & $x$ & & $x$ & \\
\hline Navicula sp. B (10 $\mu \mathrm{m})$ & & $x$ & $x$ & $x$ & $x$ & & $x$ & \\
\hline Nitzschia sp. A (25 $\mu \mathrm{m})$ & & $x$ & & $x$ & & & $x$ & \\
\hline Nitzschia sp. B (10 $\mu \mathrm{m})$ & & & & & $x$ & & $x$ & \\
\hline Pseudonitzschia delicatissima complex & (Cleve) Heiden & & & & & & $x$ & \\
\hline Pseudostaurosira brevistriata & (Grunow) D.M. Williams \& Round & & $\mathrm{x}$ & & & & $x$ & \\
\hline Thalassionema nitzschioides & (Grunow) Mereschkowsky & $x$ & & $x$ & $x$ & $x$ & $x$ & $x$ \\
\hline Thalassiosira antarctica & Comber & $x$ & $x$ & $x$ & $x$ & $x$ & $x$ & $x$ \\
\hline Thalassiosira lentiginosa & (Janisch) G. Fryxell & & $x$ & $x$ & $x$ & $x$ & & $x$ \\
\hline Thalassiosira sp. & & $x$ & $x$ & $x$ & $x$ & $x$ & $x$ & $x$ \\
\hline Centricae not identified & & $x$ & & & & & & \\
\hline Pennatae not identified & & & & & & $x$ & & $x$ \\
\hline
\end{tabular}

${ }^{*}$ In the elaboration (Table 3) the term Other indicates all the taxa excluding the genera Fragilariopsis and Thalassiosira which were the most abundant. 


\section{ACCEPTED MANUSCRIPT}

Table 2. Data on diatom abundance, biomass, diversity and main composition measured by light microscopic analysis on frozen sediment samples.

\begin{tabular}{|c|c|c|c|c|c|c|c|c|c|c|c|c|}
\hline \multirow{2}{*}{ Station } & \multirow[b]{2}{*}{$\begin{array}{l}\text { Depth } \\
\text { (m) }\end{array}$} & \multicolumn{11}{|c|}{ Diatom density in sediments } \\
\hline & & $\begin{array}{l}\text { Abundance } \\
\left(10^{6} \text { cells } / \mathrm{g}\right)\end{array}$ & $\begin{array}{l}\text { Biomass } \\
(\mu \mathrm{g} \mathrm{C} / \mathrm{g})\end{array}$ & $\begin{array}{l}\text { Chl a } \\
(\mu \mathrm{g} / \mathrm{g})\end{array}$ & $\begin{array}{c}\text { Phaeo a } \\
(\mu \mathrm{g} / \mathrm{g})\end{array}$ & $\mathrm{Chl} /$ Phaeo & $\begin{array}{l}\text { Species } \\
\text { (number) }\end{array}$ & $\begin{array}{l}\text { Diversity } \\
\left(\mathrm{H}^{\prime}, \log _{2}\right)^{1}\end{array}$ & $\begin{array}{c}\text { Fragilariopsis } \\
\text { curta } \\
(\%)\end{array}$ & $\begin{array}{c}\text { Fragilariopsis } \\
\text { spp. } \\
(\%)\end{array}$ & $\begin{array}{c}\text { Thalassiosira } \\
\text { spp. } \\
(\%)\end{array}$ & $\begin{array}{l}\text { Other } \\
\text { (\%) }\end{array}$ \\
\hline \multicolumn{13}{|c|}{ Tethys Bay } \\
\hline A & 20 & 1.90 & 170 & 2.30 & 17.3 & 0.13 & 11 & 1.66 & 71.5 & 3.83 & 4.68 & 20.0 \\
\hline$B$ & 20 & 4.17 & 522 & 1.13 & 13.8 & 0.10 & 11 & 1.43 & 77.9 & 7.08 & 4.42 & 10.6 \\
\hline \multicolumn{13}{|c|}{ Penguin Bay } \\
\hline C & 27 & 14.1 & 1646 & 11.0 & 57.5 & 0.19 & 15 & 1.80 & 71.5 & 2.53 & 2.53 & 23.5 \\
\hline \multicolumn{13}{|c|}{ Malippo pier } \\
\hline D & 19 & 0.24 & 22 & 2.14 & 9.56 & 0.22 & 18 & 3.02 & 34.0 & 17.9 & 4.26 & 43.8 \\
\hline \multicolumn{13}{|c|}{ Gerlache inlet } \\
\hline$E$ & 66 & 3.65 & 521 & 0.96 & 12.4 & 0.08 & 10 & 1.31 & 79.4 & 4.76 & 9.92 & 5.95 \\
\hline $\mathrm{F}$ & 31 & 0.27 & 25 & 0.44 & 3.10 & 0.14 & 16 & 1.89 & 71.3 & 0.70 & 4.20 & 23.8 \\
\hline $\mathrm{G}$ & 48 & 2.83 & 399 & 0.87 & 15.6 & 0.06 & 10 & 1.04 & 84.8 & 2.80 & 7.60 & 3.60 \\
\hline
\end{tabular}

* The term Other includes the taxa listed in Table 1with the exception of the genera Fragilariopsis and Thalassiosira.

${ }^{1}$ Shannon diversity index. 


\section{ACCEPTED MANUSCRIPT}

Table 3. Data on main composition of elutriate extracted by distilled water from sediments (concentration values are reported on the basis of sediment dry weight). $\mathrm{S}^{*}=$ salinity values.

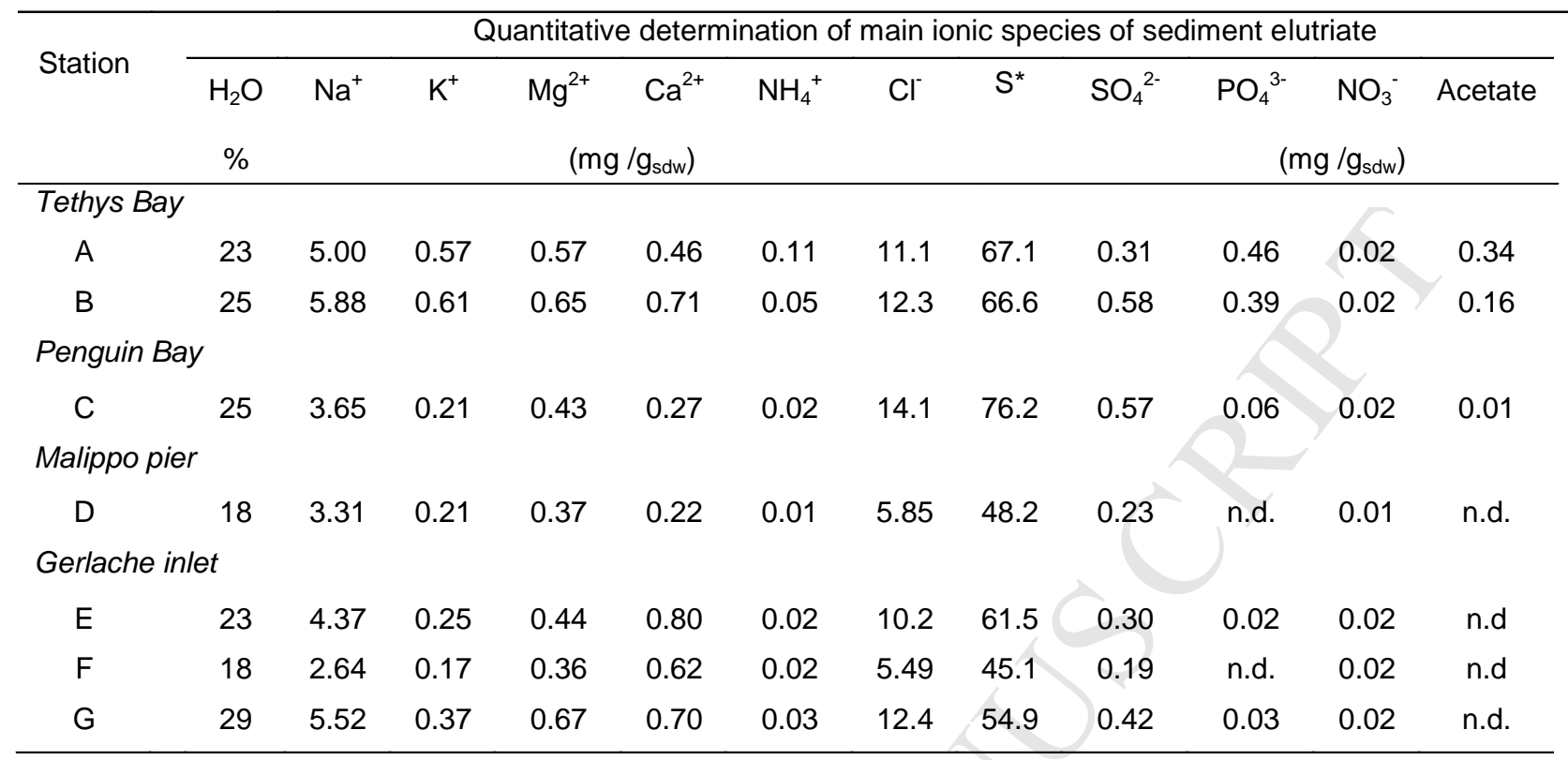


Figure 1

Click here to download high resolution image ACCEPTED MANUSCRIPT

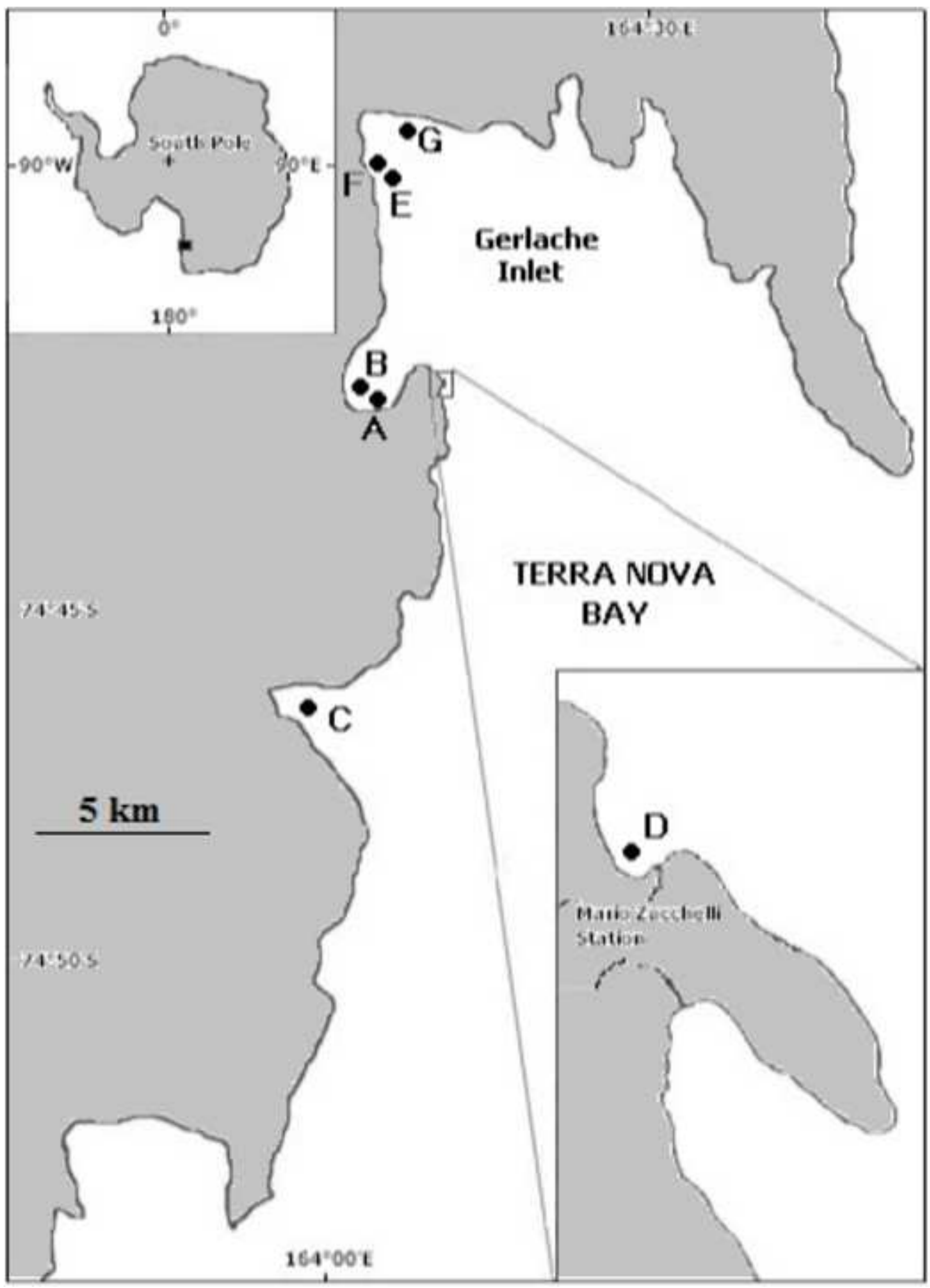


Click here to download high resolution image ACCEPTED MANUSCRIPT

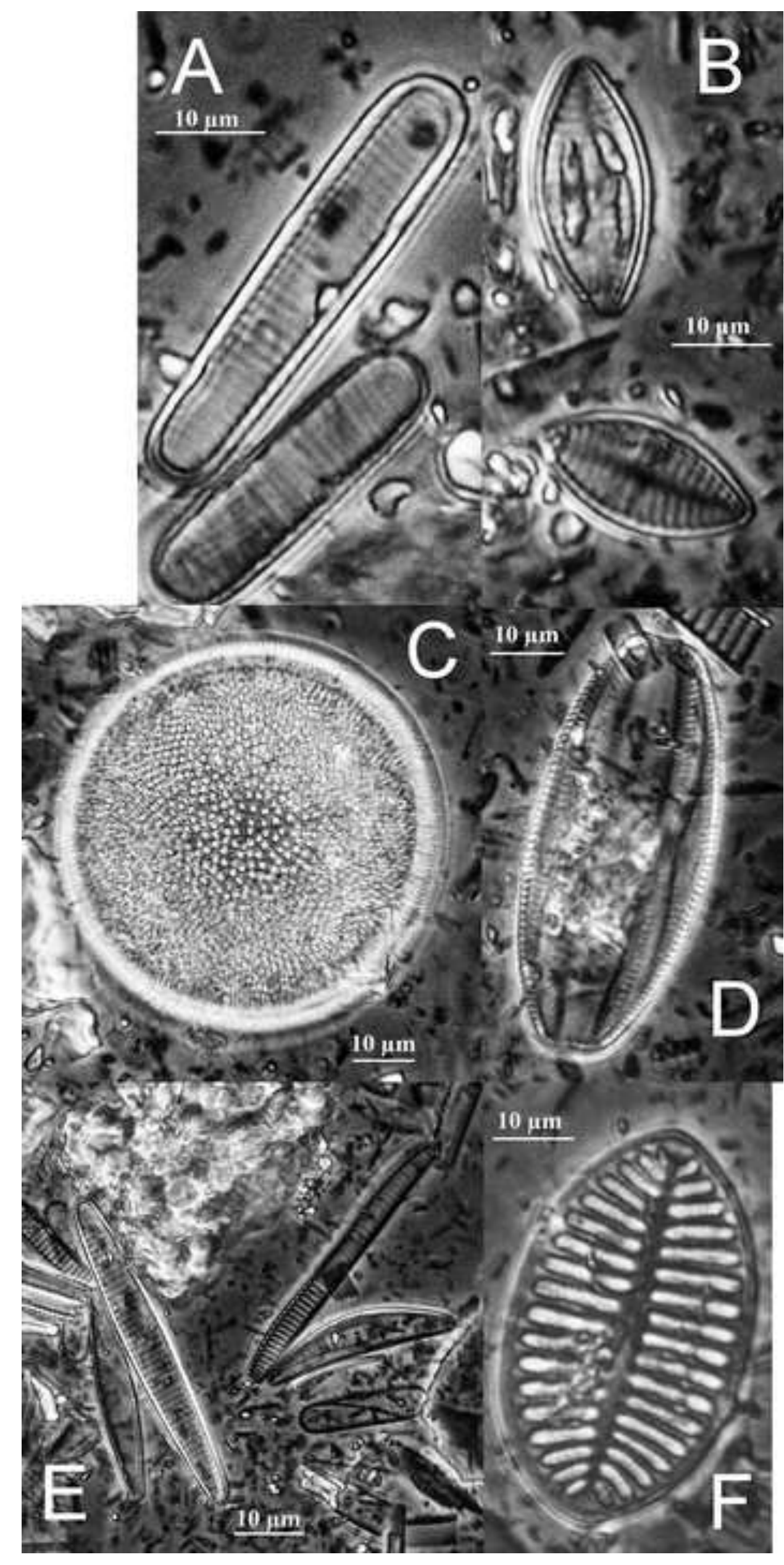

Figure 2

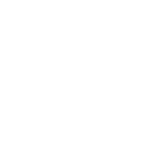




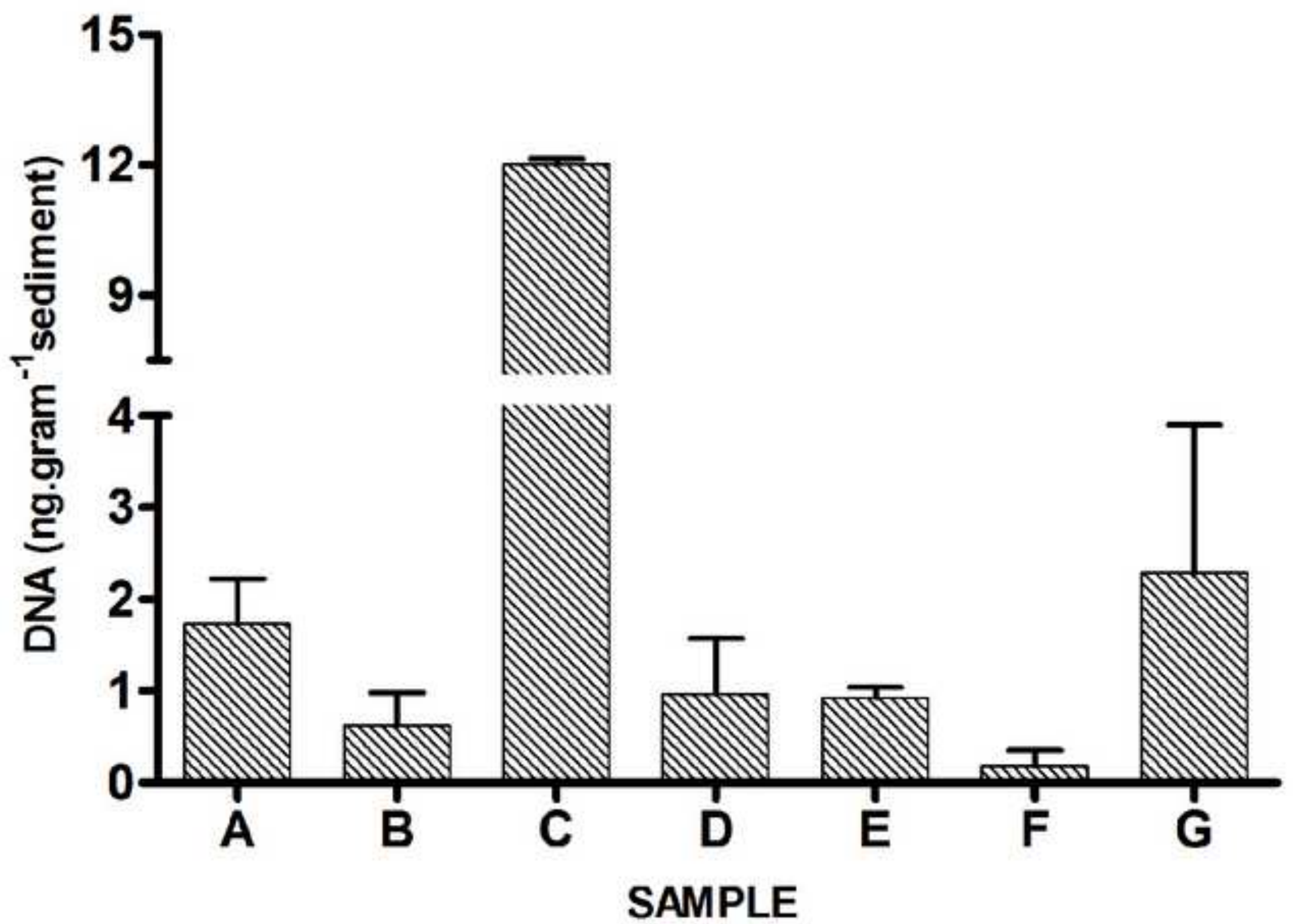




\section{Figure 5}
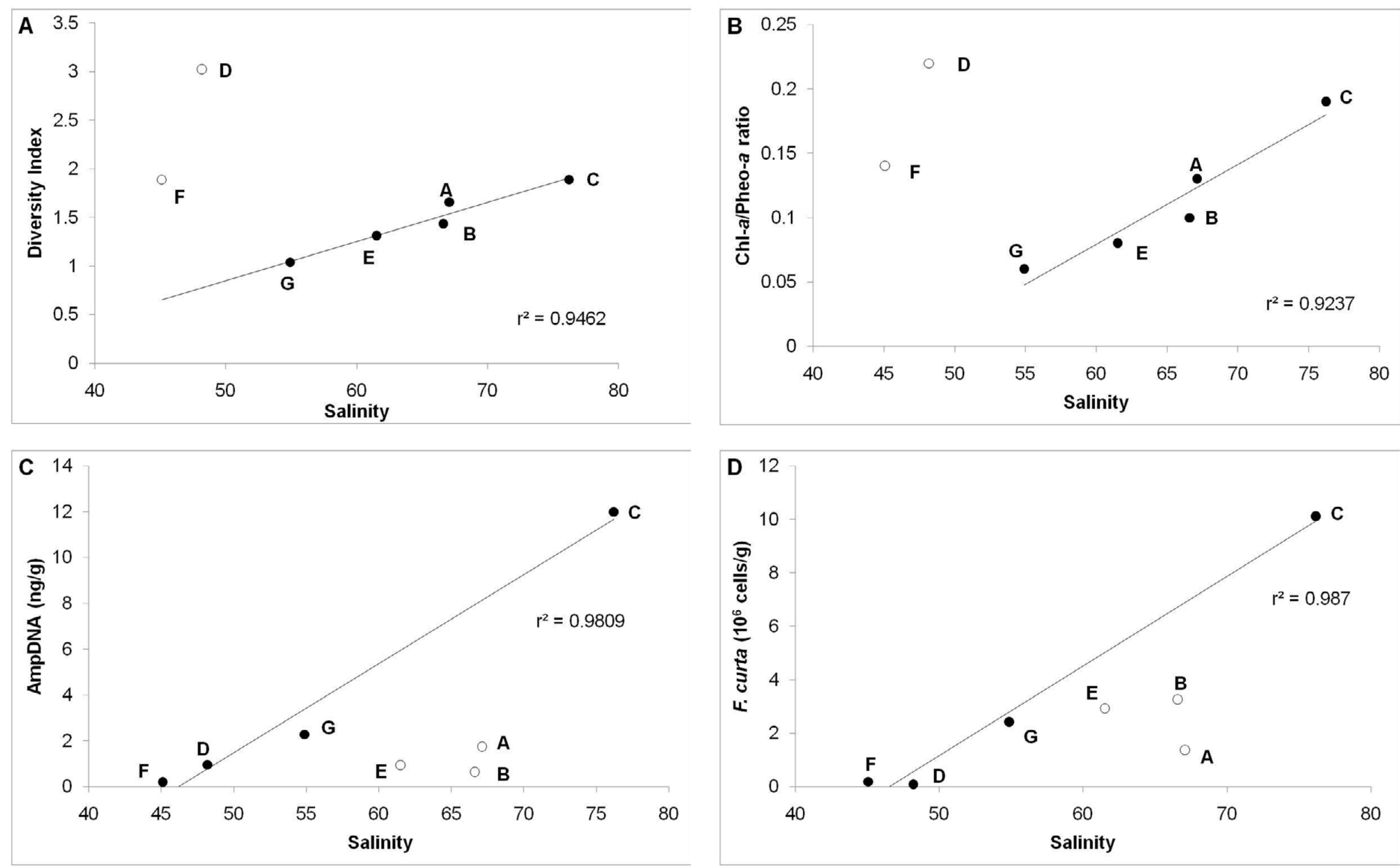